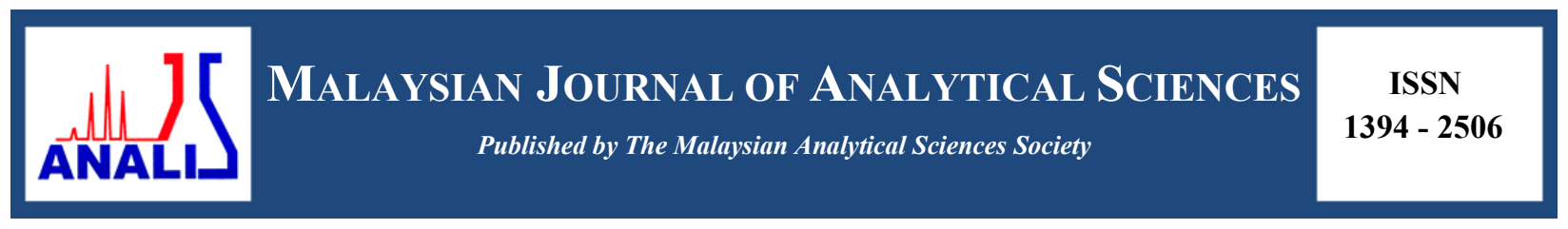

\title{
EFFECT OF ANNEALING STRATEGY ON IMPROVED PHOTOACTIVITY OF CUPROUS OXIDE NANOWIRE PREPARED USING FACILE FABRICATION STRATEGY FOR SOLAR WATER SPLITTING
}

\author{
(Kesan Strategi Pengkalsinan Terhadap Peningkatan Fotoaktiviti Nanowayar Kuprous Oksida \\ Yang Disediakan Menggunakan Cara Mudah Untuk Pembelahan Air Suria) \\ Mohd Nur Ikhmal Salehmin ${ }^{1}$, Lorna Jeffery Minggu ${ }^{1 *}$, Khuzaimah Arifin ${ }^{1}$, Mohammad Bin Kassim ${ }^{1,2}$ \\ ${ }^{I}$ Fuel Cell Institute \\ ${ }^{2}$ School of Chemical Sciences and Food Technology, Faculty of Science and Technology \\ Universiti Kebangsaan Malaysia, 43600 UKM Bangi, Selangor, Malaysia \\ *Corresponding author: lorna_jm@ukm.edu.my
}

Received: 28 November 2016; Accepted: 27 April 2017

\begin{abstract}
$\mathrm{Cu}_{2} \mathrm{O}$ photocathode such as nanowire $(\mathrm{NW})$ have shown to improve photoactivity than that nanoparticle thin film counterpart. This enhancement is attributed to enhanced photocatalytic reaction due to increase in surface active area and effective radial charge diffusion. However, the photoelectrochemical performance of reported work were rather low which need an improvement prior protection. In this study, $\mathrm{Cu}_{2} \mathrm{O}$ nanowire photocathode was fabricated using sequential wet chemical oxidation method and annealing under inert condition. Focusing on annealing step, the transformation of precursor $\mathrm{Cu}(\mathrm{OH})_{2}$ nanowire to $\mathrm{Cu}_{2} \mathrm{O}$ nanowire undergone multistep annealing with a different ramping rate under inert condition. The highest photocurrent was then compared with photocurrent generated from $\mathrm{Cu}_{2} \mathrm{O} \mathrm{NW}$ prepared with direct annealing strategy. With multistep annealing, the best photoelectrochemical performance was obtained from $\mathrm{Cu}_{2} \mathrm{O} \mathrm{NW}$ prepared at the highest ramping rate which is 1.2 folds better than that obtained with single step annealing. The photocurrent enhancement obtained in this study was attributed to favourable morphology improving light trapping. Overall, the ampleness of material source, non-toxic, simple fabrication and excellent photocatalytic performance are the pre-requisite to realize solar hydrogen production.
\end{abstract}

Keywords: cuprous oxide nanowire, photocurrent, water-splitting, hydrogen production

\section{Abstrak}

Fotokatod $\mathrm{Cu}_{2} \mathrm{O}$ yang berstrukturkan nano wayar (NW) telah menunjukkan aktiviti foto yang lebih baik berbanding filem nipis. Prestasi fotomangkin yang baik ini disumbang oleh peningkatan luas permukaan yang aktif dan keberkesanan pengaliran cas. Walaubagaimanapun, prestasi fotoelektrokimia yang telah dilaporkan masih lagi rendah dan memerlukan penambahbaikan sebelum penyalutan sebagai perlindungan untuk kestabilan fotokatod. Dalam kajian ini, $\mathrm{Cu}_{2} \mathrm{O} \mathrm{NW}$ fotokatod telah disintesis menggunakan oksidasi kimia dan pengkalsinan dalam keadaan lengai. Pada peringkat pengkalsinan, transformasi pemula $\mathrm{Cu}(\mathrm{OH})_{2}$ nanowayar kepada $\mathrm{Cu}_{2} \mathrm{O}$ nanowayar telah melalui beberapa langkah pengkalsinan dengan kadar pengkalsinan yang berbeza. Fotoarus yang tertinggi akan dibandingkan dengan fotoarus yang terhasil daripada $\mathrm{Cu}_{2} \mathrm{O}$ nanowayar yang disediakan menggunakan pengkalsinan terus. Pada pengkalsinan berperingkat, prestasi fotoelektrokimia yang terbaik didapati daripada $\mathrm{Cu}_{2} \mathrm{O} \mathrm{NW}$ yang disediakan pada kadar pengkalsinan yang paling tinggi iaitu $1.2 \mathrm{kali}$ ganda lebih baik berbanding yang didapati daripada pengkalsinan terus. Peningkatan fotoarus yang terhasil daripada kajian ini telah disumbangkan oleh kesan morfologi bahan yang berkeupayaan menyerap cahaya secara efektif. Keseluruhannya, keberadaan sumber bahan yang mencukupi, tidak toksik, cara penyediaan yang mudah, serta prestasi fotomangkin yang bagus adalah keperluan untuk merealisasikan penghasilan hidrogen dari tenaga suria. 


\section{Mohd Nur Ikhmal et al: EFFECT OF ANNEALING STRATEGY ON IMPROVED PHOTOACTIVITY OF CUPROUS OXIDE NANOWIRE PREPARED USING FACILE FABRICATION STRATEGY FOR SOLAR WATER SPLITTING}

Kata kunci: nanowayar kuprous oksida, fotoarus, pembelahan air, penghasilan hidrogen

\section{Introduction}

The photocatalytic performance of $\mathrm{Cu}_{2} \mathrm{O}$ photocathode for photoelectrochemical application can be enhanced by nanostructuring owing to its high surface area for photocatalytic reaction and alleviated issue of mismatch between the intrinsic carrier diffusion length $[1,2]$ and the light absorption depth near the band gap [3]. This single metal oxide was theoretically estimated to produce approximately $-15 \mathrm{~mA} / \mathrm{cm}^{2}$ and photoconversion efficiency of $18 \%$ based on the AM 1.5 spectrum [4]. As photocathode, recent research trend has been attempts to fabricate the photocathode with nanowire (NW) arrays film [5-8] and stabilize it using facile technique and inexpensive protective material, respectively [4, 9-12]. Prior to stabilization, priority should be given to improve the photocurrent generation that can be tapped from the photoharvester of $\mathrm{Cu}_{2} \mathrm{O}$ film. This step is crucial to compensate photocurrent reduction which might be due to poor charge transportation between overlayers or any deleterious effect of the film after the coating treatment $[9,13-15]$. $\mathrm{Cu}_{2} \mathrm{O} \mathrm{NW}$ can be fabricated using sequential wet chemical oxidation method (WCOM) $[1,6,11,16]$ followed by annealing under inert condition as one of the method which promotes facility and high quality. This method is initiated with the fabrication of $\mathrm{Cu}(\mathrm{OH})_{2} \mathrm{NW}$ as precursor using WCOM [17] before transforming to $\mathrm{Cu}_{2} \mathrm{O} \mathrm{NW}$ through annealing under inert condition. Focusing on the annealing process, the transformation of the precursor to $\mathrm{Cu}_{2} \mathrm{O} \mathrm{NW}$ involved dehydration and deoxidization step [17, 18]. Therefore it needs a multistep of annealing to provide each step with a complete transformation from $\mathrm{Cu}(\mathrm{OH})_{2}$ to $\mathrm{CuO}$ through dehydration and ultimately $\mathrm{CuO}$ to $\mathrm{Cu}_{2} \mathrm{O}$ through deoxidization.

Through literature survey on PEC application, there was only one single study which we know of following similar annealing strategy for $\mathrm{Cu}_{2} \mathrm{O}$ NW fabrication from $\mathrm{Cu}(\mathrm{OH})_{2} \mathrm{NW}$ precursor [19]. However, this study only managed to achieve photocurrent of $-2.05 \mathrm{~mA} / \mathrm{cm}^{2}$ at $0.265 \mathrm{~V}$ vs. RHE which was produced from the sample annealed at 700 ${ }^{\circ} \mathrm{C}$ for 2 hours. The low photocurrent could be due to diminishing NW structure at high annealing temperature, thus decreased surface active area for photocatalytic reaction. Other reported studies with similar material and strategy deemed to practise a direct annealing since no details were mentioned on annealing step $[5,6,8,12$, 16]. As far as photocurrent generation is concerned, the highest photocurrent ever reported for bare $\mathrm{Cu}_{2} \mathrm{O}$ from WCOM was -4.07 $\mathrm{mA} / \mathrm{cm}^{2}$ at $0 \mathrm{~V}$ vs. RHE. This PEC performance was achieved using WCOM and direct annealing at $500{ }^{\circ} \mathrm{C}$ for 2 hours under Argon flow [10]. Based on the maximum theoretical measurement of photocurrent for $\mathrm{Cu}_{2} \mathrm{O}$ photocathode mentioned above, there is indeed more room for improvement.

Therefore, in this study, an annealing with multistep strategy was used to affect an improved $\mathrm{Cu}_{2} \mathrm{O} \mathrm{NW}$ photocathode with excellent PEC performance. Since the effect of annealing temperature [5, 10], and holding time [8] were well studied, hence we investigated the effect of multistep ramping rate at $500{ }^{\circ} \mathrm{C}$ for 2 hours. For comparison, a direct annealing was conducted under similar annealing parameter that affect the highest photocurrent.

\section{The fabrication of $\mathrm{Cu}(\mathrm{OH})_{2} \mathrm{NW}$}

\section{Materials and Methods}

In most recent studies, $\mathrm{Cu}(\mathrm{OH})_{2} \mathrm{NW}$ was prepared using an established method proposed by Zhang et. al. [17]. However, in this study, the growth solution was modified by the addition of $\mathrm{NH}_{3}$. Briefly, a sheet of copper foil as substrate of $1 \mathrm{~cm}^{2}$ was cleaned in acetone, ethanol, and double distilled water $\left(\mathrm{ddH}_{2} \mathrm{O}\right)$ for 5 minutes each, consecutively. The wet $\mathrm{Cu}$ foils were then dried with nitrogen flow prior to immersion in growth solution. The growth solution composed of $2.67 \mathrm{M} \mathrm{NaOH}$ (Amreck), $0.133 \mathrm{M}\left(\mathrm{NH}_{4}\right)_{2} \mathrm{~S}_{2} \mathrm{O}_{8}$ (Sigma), and $4.26 \% \mathrm{NH}_{3}$ (Merck), were dissolved in $\mathrm{ddH}_{2} \mathrm{O}$ as reaction media. After 25 minutes of reaction, blue film appeared covering the substrate indicating the growth of $\mathrm{Cu}(\mathrm{OH})_{2} \mathrm{NW}$. Then, the grown film was rinsed with $\mathrm{ddH}_{2} \mathrm{O}$ and dried in air.

\section{The conversion of $\mathrm{Cu}(\mathrm{OH})_{2} \mathrm{NW}$ to $\mathrm{Cu}_{2} \mathrm{O} \mathrm{NW}$}

The as-prepared $\mathrm{Cu}(\mathrm{OH})_{2} \mathrm{NW}$ film was then subjected for annealing to be converted to $\mathrm{Cu}_{2} \mathrm{O}$ NW under $\mathrm{N}_{2}$ flow. Three levels of ramping rate at 1,3 , and $5{ }^{\circ} \mathrm{C} /$ min were carried out to reach final temperature of $500{ }^{\circ} \mathrm{C}$ for 2 hours. Routinely, the furnace was first evacuated with vacuum and followed by nitrogen sparging alternately for 3 cycles. Then, from room temperature, the furnace was first raised to $120{ }^{\circ} \mathrm{C}$ with $5{ }^{\circ} \mathrm{C} / \mathrm{min}$ ramping rate and held at $120{ }^{\circ} \mathrm{C}$ 
for 60 minutes before ramped up to $180{ }^{\circ} \mathrm{C}$ for 1 hour and held for another 1 hour. With different ramping rate as mentioned, the temperature was finally raised to $500{ }^{\circ} \mathrm{C}$ and held for another 2 hours before cooling down. For comparison on PEC performance, a direct annealing (without multistep) was conducted at the pre-determined ramping rate under similar annealing condition. For simplicity, hereafter, the $\mathrm{Cu}_{2} \mathrm{O} \mathrm{NW}$ sample prepared with multistep annealing at 1,3 , and $5{ }^{\circ} \mathrm{C} /$ min ramping rate were denoted as $\mathrm{Cu}_{2} \mathrm{O}-\left(1{ }^{\circ} \mathrm{C} / \mathrm{min}\right), \mathrm{Cu}_{2} \mathrm{O}-\left(3^{\circ} \mathrm{C} / \mathrm{min}\right)$, and $\mathrm{Cu}_{2} \mathrm{O}-\left(5^{\circ} \mathrm{C} / \mathrm{min}\right)$, respectively. Whereas sample labelled with $\mathrm{Cu}_{2} \mathrm{O}-\left(5^{\circ} \mathrm{C} / \mathrm{min}\right)\left(\mathrm{D}\right.$.A) stands for $\mathrm{Cu}_{2} \mathrm{O}$ NW which prepared with direct annealing strategy at $5{ }^{\circ} \mathrm{C} / \mathrm{min}$.

\section{Structural characterization}

The morphology of the samples was characterized using a Variable Pressure Scanning Electron Microscope (VPSEM). The crystallinity of the samples were determined by X-ray diffractometer (XRD) (Bruker D8 Advance), using $\mathrm{Cu} \mathrm{K} \alpha$ radiation. Whereas, the $\mathrm{UV}$-vis diffuse reflectance spectra were determined with a spectrophotometer (Perkin Elmer, Lambda 950).

\section{Photoelectrochemical measurement}

The photoresponse of the samples were measured using three electrodes configuration contained in a photocell with expose area of $0.196 \mathrm{~cm}^{2}$. The fabricated photoelectrode was assigned as working electrode, $\mathrm{Ag} / \mathrm{AgCl}$ as reference electrode, and platinum as counter electrode. $\mathrm{Cu}$ tape was connected to photoelectrode sample and clamped before it is filled with electrolyte. Those electrodes were immersed in $0.5 \mathrm{M} \mathrm{Na}_{2} \mathrm{SO}_{4}$ solution which was purged with Argon for 10 minutes prior to measurement. The photocurrent measurement was acquired under AM 1.5 Xenon light irradiation at $100 \mathrm{~mW} / \mathrm{cm}^{2}$. The photocurrent density was then determined as a result of subtraction between light and dark current and divided by the sample's exposed area.

\section{Characterization of $\mathrm{Cu}_{2} \mathrm{O} \mathrm{NW}$ film}

\section{Results and Discussion}

The transformation of $\mathrm{Cu}(\mathrm{OH})_{2} \mathrm{NW}$ to $\mathrm{Cu}_{2} \mathrm{O} \mathrm{NW}$ depicts a morphology changes from a straight-standing $\mathrm{Cu}(\mathrm{OH})_{2}$ $\mathrm{NW}$ to bendy and segmented $\mathrm{Cu}_{2} \mathrm{O}$ NW (Figure 1). The changes can be seen started at $180{ }^{\circ} \mathrm{C}$ (Figure $1 \mathrm{~b}$ ) where a straight $\mathrm{NW}$ of $\mathrm{Cu}(\mathrm{OH})_{2} \mathrm{NW}$ was appeared bendy and the films turned black (insert (1b). As temperature increased to $500{ }^{\circ} \mathrm{C}$ at different ramping rate and held for 2 hours, a dramatic change on the NW strand was noticed (Figure $1 \mathrm{c}, 1 \mathrm{~d}$, and 1e) indicating $\mathrm{Cu}_{2} \mathrm{O}$ NW was produced as evidenced from XRD analysis Figure 2. It was reported that the curly and bendy NW after annealing was due to the stress of phase changes resulted from oxygen separation from the lattice of $\mathrm{CuO}$ [8].
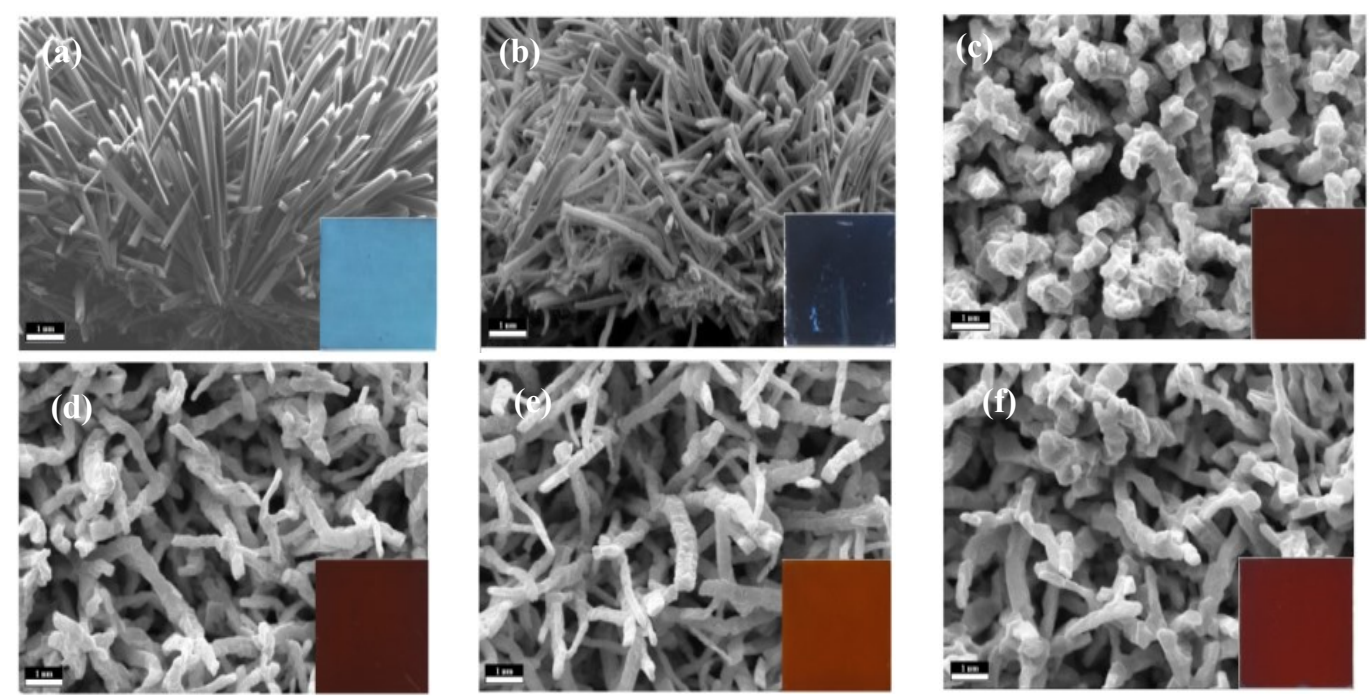

Figure 1. SEM images of a) $\left.\mathrm{Cu}(\mathrm{OH})_{2} \mathrm{NW}, \mathrm{b}\right) \mathrm{CuO} \mathrm{NW}, \mathrm{Cu}_{2} \mathrm{O}$ NW prepared at multistep annealing with different ramping rate at c) $1{ }^{\circ} \mathrm{C} / \mathrm{min}$, d) $3{ }^{\circ} \mathrm{C} / \mathrm{min}$, e) $5{ }^{\circ} \mathrm{C} / \mathrm{min}$, and f) without multistep $\mathrm{Cu}_{2} \mathrm{O} \mathrm{NW}-\left(5^{\circ} \mathrm{C} / \mathrm{min}\right)$ (D.A) 


\section{Mohd Nur Ikhmal et al: EFFECT OF ANNEALING STRATEGY ON IMPROVED PHOTOACTIVITY OF CUPROUS OXIDE NANOWIRE PREPARED USING FACILE FABRICATION STRATEGY FOR SOLAR WATER SPLITTING}

The phase transformation from $\mathrm{CuO}$ to $\mathrm{Cu}_{2} \mathrm{O}$ is explainable with deoxidization reaction where oxygen molecules was removed from the $\mathrm{CuO}$ lattice and reducing the ionic state from 2 to 1 becoming $\mathrm{Cu}_{2} \mathrm{O}$ [17]. Along with morphology changes, the NW dimension also changed accordingly as tabulated in Table 1.

Table 1. The dimension of nanowire before and after annealing measured using ImageJ software

\begin{tabular}{lcc}
\hline Samples & Length $(\boldsymbol{\mu m})$ & Width $(\boldsymbol{\mu m})$ \\
\hline $\mathrm{Cu}(\mathrm{OH})_{2} \mathrm{NW}$ & $5.60 \pm 0.20$ & $0.40 \pm 0.02$ \\
$\mathrm{Cu}_{2} \mathrm{O}-\left(1{ }^{\circ} \mathrm{C} / \mathrm{min}\right)$ & $2.72 \pm 0.14$ & $0.82 \pm 0.14$ \\
$\mathrm{Cu}_{2} \mathrm{O}-\left(3^{\circ} \mathrm{C} / \mathrm{min}\right)$ & $3.12 \pm 0.09$ & $0.45 \pm 0.01$ \\
$\mathrm{Cu}_{2} \mathrm{O}-\left(5^{\circ} \mathrm{C} / \mathrm{min}\right)$ & $4.07 \pm 0.08$ & $0.39 \pm 0.08$ \\
$\mathrm{Cu}_{2} \mathrm{O}-\left(5{ }^{\circ} \mathrm{C} / \mathrm{min}\right)($ D.A $)$ & $3.33 \pm 0.07$ & $0.56 \pm 0.04$ \\
\hline
\end{tabular}

The results obtained here can be concluded that, the length and width of NW arrays were shortened and widen as the ramping rate decreased. This observation is attributed to agglomeration of NW structure affected by long annealing time imposed by the lowest ramping rate. A long annealing time induced the increase in crystal size which is in agreement with reported study [8]. On the other hand, samples annealed at higher ramping rate has shorter annealing time and were not severely impacted by agglomeration, hence appeared to be the longest NW. Although $\mathrm{Cu}_{2} \mathrm{O}-\left(5^{\circ} \mathrm{C} / \mathrm{min}\right)$ (D.A) sample was prepared with the shortest annealing time, its $\mathrm{NW}$ length is shorter than that measured for $\mathrm{Cu}_{2} \mathrm{O}-\left(5^{\circ} \mathrm{C} / \mathrm{min}\right)$. This shows that during the multisteps annealing the different holding time at different temperatures affected the agglomeration rate differently than during direct annealing. Furthermore, it is reported that the curly and bendy NW after annealing was due to the stress of phase changes resulted from oxygen separation from the lattice of $\mathrm{CuO}[8]$.

In Figure 2, an overlayer of XRD pattern of the samples pre and post annealing are displayed. A distinct XRD pattern of each sample reflecting a complete transformation from $\mathrm{Cu}$ to $\mathrm{Cu}(\mathrm{OH})_{2}, \mathrm{CuO}$ and subsequently to $\mathrm{Cu}_{2} \mathrm{O}$ after annealing. $\mathrm{Cu}_{2} \mathrm{O}$ is known with dominant peak of 111 phase which claimed to be responsible for good PEC performance $[5,20]$. This particular peak has increased in intensity as the ramping rate decreased which remarked an improved crystallinity with longer annealing time (Figure 2). Contrastingly, the $\mathrm{Cu}_{2} \mathrm{O}-\left(5^{\circ} \mathrm{C} / \mathrm{min}\right)$ (D.A) has shown a higher peak intensity than that obtained by $\mathrm{Cu}_{2} \mathrm{O}-\left(5^{\circ} \mathrm{C} / \mathrm{min}\right)$. The peculiar results on $\mathrm{NW}$ dimension and crystallinity demonstrated by $\mathrm{Cu}_{2} \mathrm{O}-\left(5{ }^{\circ} \mathrm{C} / \mathrm{min}\right)(\mathrm{D}$.A) sample might be clarified through the study of effect of annealing temperature on dominant peak intensity through direct annealing strategy.

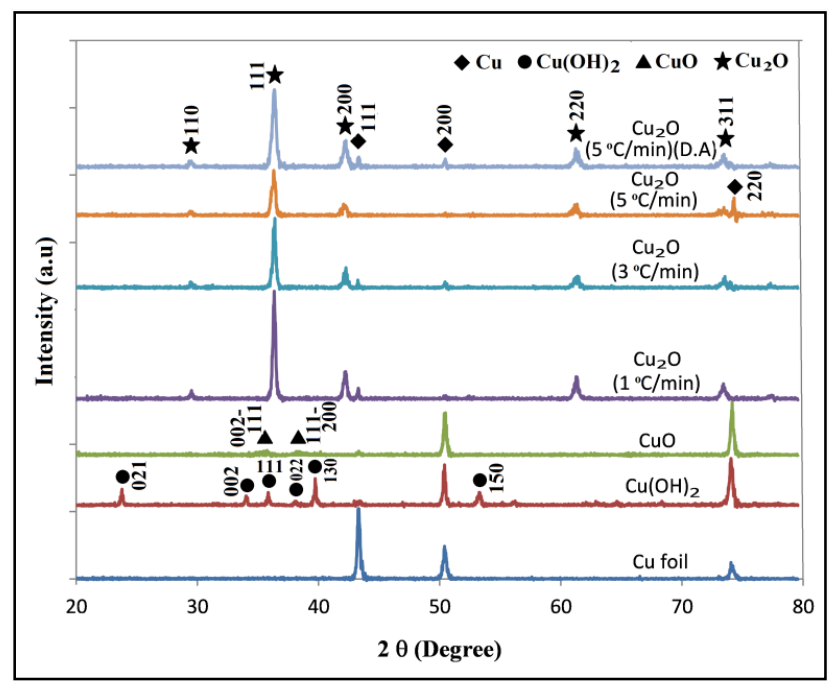

Figure 2. The overlayer of XRD pattern of samples pre and post annealing 
The photoabsorption of the annealed samples were measured using diffuse reflectance spectrophotometry (Figure 3a). The higher reflectance indicates lower light absorption. Therefore, in this study, $\mathrm{Cu}_{2} \mathrm{O}-\left(5^{\circ} \mathrm{C} / \mathrm{min}\right)$ has the higher capacity in absorbing light than $\mathrm{Cu}_{2} \mathrm{O}-\left(1{ }^{\circ} \mathrm{C} / \mathrm{min}\right)$ specifically within $300-500 \mathrm{~nm}$ light spectrum frame. This observation has the correlation with the morphology which structured at different ramping rate. As mentioned earlier, short and bulky NW arrays were made of large crystal which featured with low surface area to volume ratio. Dimensionally, it did not encourage high light absorption capacity. Long and slim NW arrays, on the other hand, were made of small crystal which structured at relatively shorter annealing time, thus enhancing light trapping efficiency. These observations are in line with the previous reported study with similar research material and strategy [8]. In order to determine the band gap of each $\mathrm{Cu}_{2} \mathrm{O}$ NW sample, Kubelka Munk-plotting function was used against band gap energy [21]. From the K-M plotting (Figure 3b), a very close band gap for all samples were extrapolated to be $2.05 \pm 0.01 \mathrm{eV}$. The obtained band gap values are consistent with reported value and within the favourable band gap frame (1.8-2.1 eV) for PEC application as suggested by Murphy et al. [22].

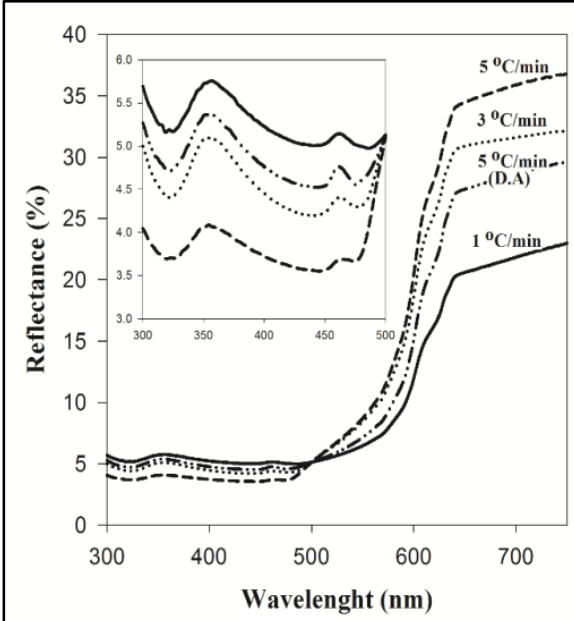

(a)

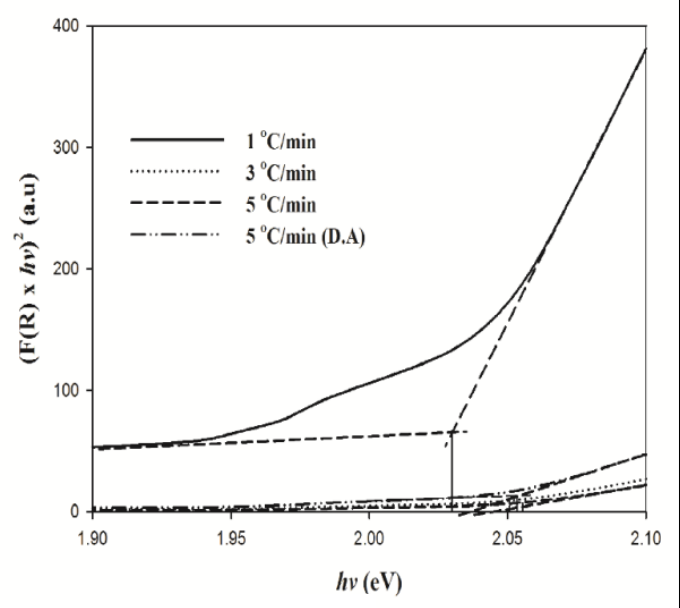

(b)

Figure 3. Diffuse reflectance spectra of a) $\mathrm{Cu}_{2} \mathrm{O}$ NW prepared at different ramping rate and annealing step; the insert shows the light reflectance value within a light spectrum frame, b) the corresponding KubelkaMunk plot for the $\mathrm{Cu}_{2} \mathrm{O} \mathrm{NW}-\left(1^{\circ} \mathrm{C} / \mathrm{min}\right), \mathrm{Cu}_{2} \mathrm{O} \mathrm{NW}-\left(3^{\circ} \mathrm{C} / \mathrm{min}\right)$, and $\mathrm{Cu}_{2} \mathrm{O} \mathrm{NW}-\left(5^{\circ} \mathrm{C} / \mathrm{min}\right)$, and $\mathrm{Cu}_{2} \mathrm{O} \mathrm{NW}-$ $\left(5^{\circ} \mathrm{C} / \mathrm{min}\right)(\mathrm{D} . \mathrm{A})$

\section{Photocurrent measurement}

The photocurrent appears to be influenced by the morphology of the NW which was affected by the ramping rate (Figure 2). A longer and thinner NW produced by a higher ramping rate (shorter time) enhanced photocurrent. Although the XRD peak intensity reduced with the higher ramping rate (shorter annealing time), this does not seem to reduce the photocurrent. Therefore, the NW morphology appears to have more effect on the photocurrent than the XRD peak intensity. This is shown by $\mathrm{Cu}_{2} \mathrm{O}-\left(5^{\circ} \mathrm{C} / \mathrm{min}\right)$ produced the highest photocurrent which benefitted from the long and slimmer NW which concomitantly provides high surface active area [23, 24], and improved radial charge diffusion for a better photocatalytic reaction [23, 25]. As the band gaps are very similar (Figure 3b), the photocurrent appears to be influenced solely by the morphology of the NW. Whereas, a lower ramping rate (longer annealing time) produced shorter and wider NW resulting in lower photocurrent. Even though the direct annealing strategy $\left(\mathrm{Cu}_{2} \mathrm{O}-\left(5^{\circ} \mathrm{C} / \mathrm{min}\right)(\mathrm{D} . \mathrm{A})\right)$ has the shortest annealing time, but the photocurrent produced was significantly lower than that obtained by the sample $\mathrm{Cu}_{2} \mathrm{O}-\left(5^{\circ} \mathrm{C} / \mathrm{min}\right)$. This can also be observed from the NW morphology as well, where $\mathrm{Cu}_{2} \mathrm{O}-\left(5^{\circ} \mathrm{C} / \mathrm{min}\right)$ (D.A) has shorter and wider $\mathrm{NW}$ compared to $\mathrm{Cu}_{2} \mathrm{O}-\left(5^{\circ} \mathrm{C} / \mathrm{min}\right)$. Furthermore, $\mathrm{Cu}_{2} \mathrm{O}-(5$ $\left.{ }^{\circ} \mathrm{C} / \mathrm{min}\right)\left(\mathrm{D}\right.$.A) reflects light higher than $\mathrm{Cu}_{2} \mathrm{O}-\left(5^{\circ} \mathrm{C} / \mathrm{min}\right)(\mathrm{D}$.A) which explained the photocurrent reduction as shown in Figure 4. Eventhough $\mathrm{Cu}_{2} \mathrm{O}-\left(5^{\circ} \mathrm{C} / \mathrm{min}\right)(\mathrm{DA})$ was prepared at the shortest annealing time, however the multistep annealing used in the $\mathrm{Cu}_{2} \mathrm{O}-\left(5^{\circ} \mathrm{C} / \mathrm{min}\right)$ preparation improved the $\mathrm{NW}$ morphology which resulted in enhanced 
photocurrent. This result suggested that multistep annealing is critical to affect complete phase transformation during the course of annealing.

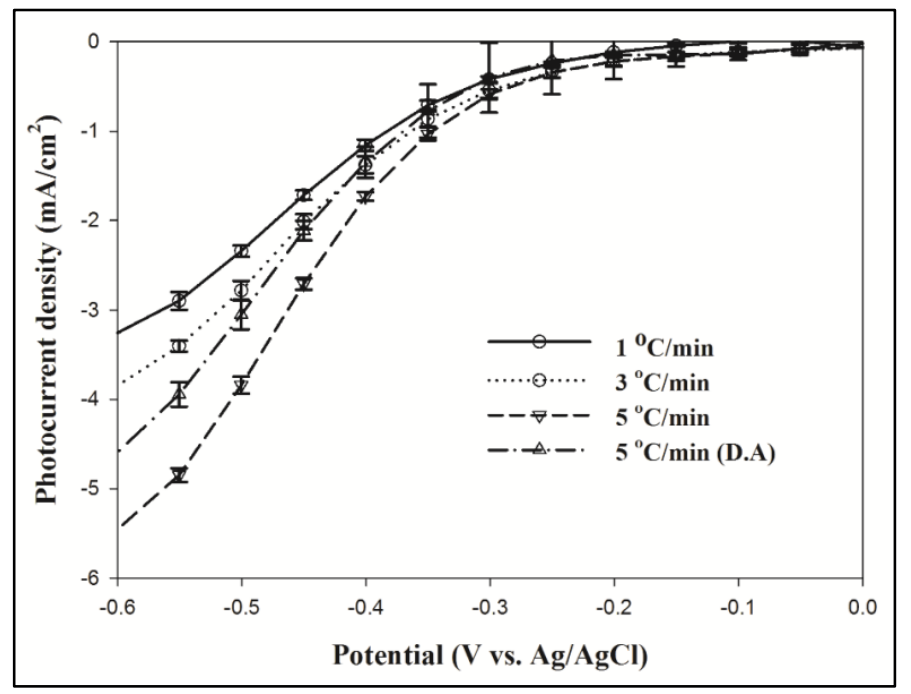

Figure 4. Photocurrent measurement generated from $\mathrm{Cu}_{2} \mathrm{O}$ annealed at different ramping rate and annealing step

\section{Conclusion}

In this study, the photoactivity of $\mathrm{Cu}_{2} \mathrm{O}$ NW was markedly influenced by the effect of ramping rate which found to be analogous with the effect of annealing time. With longer and slimmer $\mathrm{NW}, \mathrm{Cu}_{2} \mathrm{O}-\left(5^{\circ} \mathrm{C} / \mathrm{min}\right)$ sample exhibited the highest photoabsorption and photocatalytic activity, thus resulted with the highest photocurrent generation relative to the other $\mathrm{Cu}_{2} \mathrm{O}$ sample. This study also suggesting that a multistep annealing is necessary to prepare a good quality of $\mathrm{Cu}_{2} \mathrm{O} \mathrm{NW}$ photocathode. Technically, this low cost and simple fabrication technique for $\mathrm{Cu}_{2} \mathrm{O} \mathrm{NW}$ photocathode was adequate to produce a highly efficient photoelectrode for PEC system. The next step is to stabilize the $\mathrm{Cu}_{2} \mathrm{O}$ NW from photocorrosion problem which remain the biggest challenge.

\section{Acknowledgement}

This work was financially supported by DLP-2014 008 \& FRGS/1/2014/SG01/UKM/02/1.

\section{References}

1. Hacialioglu, S., Meng, F. and Jin, S. (2012). Facile and mild solution synthesis of $\mathrm{Cu}_{2} \mathrm{O}$ nanowires and nanotubes driven by screw dislocations. Chemical Communications, 48(8): $1174-1176$.

2. De Jongh, P., Vanmaekelbergh, D. and Kelly, J. (1999). $\mathrm{Cu}_{2} \mathrm{O}$ : Electrodeposition and characterization. Chemistry of Materials, 11(12): 3512 - 3517.

3. Engel, C. J., Polson, T. A., Spado, J. R., Bell, J. M. and Fillinger, A. (2008). Photoelectrochemistry of Porous P-Cu ${ }_{2} \mathrm{O}$ Films. Journal of the Electrochemical Society, 155(3): 37 - 42.

4. Paracchino, A., Laporte, V., Sivula, K., Grätzel, M. and Thimsen, E. (2011). Highly active oxide photocathode for photoelectrochemical water reduction. Nature materials, 10(6): $456-461$.

5. Hsu, Y.-K., Yu, C.-H., Chen, Y.-C. and Lin, Y.-G. (2013). Fabrication of coral-like $\mathrm{Cu}_{2} \mathrm{O}$ nanoelectrode for solar hydrogen generation. Journal of Power Sources, 242: 541 - 547.

6. Hsu, Y.-K., Yu, C.-H., Chen, Y.-C. and Lin, Y.-G. (2013). Synthesis of novel $\mathrm{Cu}_{2} \mathrm{O}$ micro/nanostructural photocathode for solar water splitting. Electrochimica Acta, 105: $62-68$.

7. Luo, J., Steier, L., Son, M.-K., Schreier, M., Mayer, M. T. and Grätzel, M. (2016). $\mathrm{Cu}_{2} \mathrm{O}$ nanowire photocathodes for efficient and durable solar water splitting. Nano Letters, 16(3): 1848 - 1857. 
8. Li, C., Li, Y. and Delaunay, J.-J. (2013). A novel method to synthesize highly photoactive $\mathrm{Cu}_{2} \mathrm{O}$ microcrystalline films for use in photoelectrochemical cells. ACS Applied Materials \& Interfaces, 6(1): 480 486.

9. Zhang, Z., Dua, R., Zhang, L., Zhu, H., Zhang, H. and Wang, P. (2013). Carbon-layer-protected cuprous oxide nanowire arrays for efficient water reduction. ACS Nano, 7(2): $1709-1717$.

10. Li, Y., Zhang, X., Chen, H. and Li, Y. (2015). Thermal conversion synthesis of $\mathrm{Cu}_{2} \mathrm{O}$ photocathode and the promoting effects of carbon coating. Catalysis Communications, 66: $1-5$.

11. Dubale, A. A., Su, W.-N., Tamirat, A. G., Pan, C.-J., Aragaw, B. A., Chen, H.-M., Chen, C.-H. and Hwang, B.J. (2014). The synergetic effect of graphene on $\mathrm{Cu}_{2} \mathrm{O}$ nanowire arrays as a highly efficient hydrogen evolution photocathode in water splitting. Journal of Materials Chemistry A, 2(43): $18383-18397$.

12. Tilley, S. D., Schreier, M., Azevedo, J., Stefik, M. and Graetzel, M. (2014). Ruthenium oxide hydrogen evolution catalysis on composite cuprous oxide water-splitting photocathodes. Advanced Functional Materials, 24(3): $303-311$.

13. Paracchino, A., Mathews, N., Hisatomi, T., Stefik, M., Tilley, S. D. and Grätzel, M. (2012). Ultrathin films on copper(I) oxide water splitting photocathodes: A study on performance and stability. Energy \& Environmental Science, 5(9): 8673 - 8681.

14. Morales-Guio, C. G., Tilley, S. D., Vrubel, H., Grätzel, M. and Hu, X. (2014). Hydrogen evolution from a copper (i) oxide photocathode coated with an amorphous molybdenum sulphide catalyst. Nature Communications, 5: $1-7$.

15. Li, C., Hisatomi, T., Watanabe, O., Nakabayashi, M., Shibata, N., Domen, K. and Delaunay, J.-J. (2015). Positive onset potential and stability of $\mathrm{Cu}_{2} \mathrm{O}$-based photocathodes in water splitting by atomic layer deposition of a $\mathrm{Ga}_{2} \mathrm{O}_{3}$ buffer layer. Energy \& Environmental Science, 8(5): $1493-1500$.

16. Lin, C.-Y., Lai, Y.-H., Mersch, D. and Reisner, E. (2012). $\mathrm{Cu}_{2} \mathrm{O} \mid \mathrm{NiO}_{\mathrm{X}}$ nanocomposite as an inexpensive photocathode in photoelectrochemical water splitting. Chemical Science, 3(12): 3482 -3487.

17. Zhang, W., Wen, X., Yang, S., Berta, Y. and Wang, Z. L. (2003). Single-crystalline scroll-type nanotube arrays of copper hydroxide synthesized at room temperature. Advanced Materials, 15(10): $822-825$.

18. Lu, C., Qi, L., Yang, J., Zhang, D., Wu, N. and Ma, J. (2004). Simple template-free solution route for the controlled synthesis of $\mathrm{Cu}(\mathrm{OH})_{2}$ and $\mathrm{CuO}$ nanostructures. The Journal of Physical Chemistry B, 108(46): 17825 -17831 .

19. Kargar, A., Partokia, S. S., Niu, M. T., Allameh, P., Yang, M., May, S., Cheung, J. S., Sun, K., Xu, K. and Wang, D. (2014). Solution-grown 3D $\mathrm{Cu}_{2} \mathrm{O}$ networks for efficient solar water splitting. Nanotechnology, 25(20): $1-9$.

20. Kim, T. G., Oh, H.-B., Ryu, H. and Lee, W.-J., (2014). The study of post annealing effect on $\mathrm{Cu}_{2} \mathrm{O}$ thin-films by electrochemical deposition for photoelectrochemical applications. Journal of Alloys and Compounds, 612: $74-79$.

21. Wilkinson, F. (1986). Diffuse reflectance flash photolysis. Journal of the Chemical Society, Faraday Transactions 2: Molecular and Chemical Physics, 82(12): 2073 - 2081.

22. Murphy, A., Barnes, P., Randeniya, L., Plumb, I., Grey, I., Horne, M. and Glasscock, J. (2006). Efficiency of solar water splitting using semiconductor electrodes. International Journal of Hydrogen Energy, 31(14): 1999 2017.

23. Dai, P., Xie, J., Mayer, M. T., Yang, X., Zhan, J. and Wang, D. (2013). Solar hydrogen generation by silicon nanowires modified with platinum nanoparticle catalysts by atomic layer deposition. Angewandte Chemie International Edition, 52(42): 11119 - 11123.

24. Walter, M. G., Warren, E. L., McKone, J. R., Boettcher, S. W., Mi, Q., Santori, E. A. and Lewis, N. S. (2010). Solar water splitting cells. Chemical Reviews, 110(11): 6446 - 6473.

25. Dai, P., Li, W., Xie, J., He, Y., Thorne, J., McMahon, G., Zhan, J. and Wang, D. (2014). Forming buried junctions to enhance the photovoltage generated by cuprous oxide in aqueous solutions. Angewandte Chemie International Edition, 53(49): 13493 - 13497. 